1901. $\ldots \ldots \ldots \ldots$ The Pear and Cherry Slug (Eriocampa limacina Retz), generally known as Selandria cerasi, with Notes on Australian Sawflies. Agric Gazette N. S. Wales 1901, pp. 1-11, 4 pls.

1918. Notes on Australian Sawflies (Tenthredinidæ). Proc. Linn. Soc. N. S. Wales 43 , 1918, pp. 668-726.

\title{
TWO NEW ANTS FROM BOLIVIA
}

(Results of the Mulford Biological Exploration.-Entomology.)

By Wm. M. ManN.

BUREAU OF ENTOMOLOGY, U. S. DElARTMENT OF AGRICULTURE.

Among the material collected in Bolivia and so far studied, two ants are of especial interest. One belongs to an aberrant undescribed genus of "driver ant" (Dorylinæ) and the other is a Ponerine species very similar to Probolomyrmex filiformis Mayr known from workers described in 1901, from Port Elizabeth, Cape Colony. The latter is an example of discontinuous distribution, such as is frequently found among the Ponerine anta. but it is the first case in its subfamily of a South African and South American relationship.

\section{Subfamily Dorylince}

\section{Leptanilloides gen. nov.}

Worker.-Small, slender, monomorphic. Head elongate, subquadrate, anterior portion of front rather strongly impressed. Clypeus short. Frontal carinæ very short, fused between the antennæ, separated anteriorly and bordering the antennal fossæ. Cheeks with a strong carina, which projects forward as a blunt tooth. Mandibles with distinct basal and apical portions separated by a rounded angle. Eyes absent. Antennæ 12-jointed, stout, scape short, funiculus moderately thickened distally, 
joints submoniliform. Thorax long, slender and flattened; mesoëpinotum compressed laterally; promesonotal impression strong; mesoëpinotal impression obsolete. Epinotum unarmed. Petiole subcylindrical, not pedunculate. Postpetiole shorter and broader than the petiole. Gaster long and slender, the three segments visible from above separated by strong constrictions. Legs, long spines of anterior tibiæ very strongly pectinate, those of middle tibiæ small, of the posterior pair moderately pectinate. Claws simple.

Genotype.-Leptanilloides biconstricta, new species.

Leptanilloides biconstricta sp. nov. (Fig. 1)

Worker.-Length 1.80-2 $\mathrm{mm}$.

Head subquadrate, very slightly narrowed behind, more than twice as long as broad, sides nearly straight and parallel; occipital corners rounded, border feebly concave. Mandibles slender; their blades edentate. Anterior border of clypeus straight. Antennæ stout, scapes clavate, extending about three-eighths the distance to occipital borders; first funicular joint rounded, broad $r$ and longer than the second; joints 2-10 slightly transverse, gradually increasing in size toward apex; terminal joint about as long as the two preceding together. Thorax and epinotum elongate, slender, flat above; pronotum from above broadest at humeri, with sides feebly convex; mesoëpinotum seen from above, quadrate, two and a half times as long as broad, with nearly straight sides; epinotal declivity very short and rounding into the basal portion. Petiolar node from above a little longer and two-thirds as broad as the post petiole, very slightly narrowed from front to rear and with straight sides; in profile slightly convex above, the ventral outline convex at anterior half and concave behind, projected anteriorly as a blunt cone. Postpetiole in profile rather strongly convex beneath, feebly above; from above a little longer than broad, feebly broadened from front to rear, with straight anterior and posterior borders and nearly straight sides. First gastric 
segment a little longer than the second or third. Legs long, the femora swollen and the tibiæ enlarged apically.
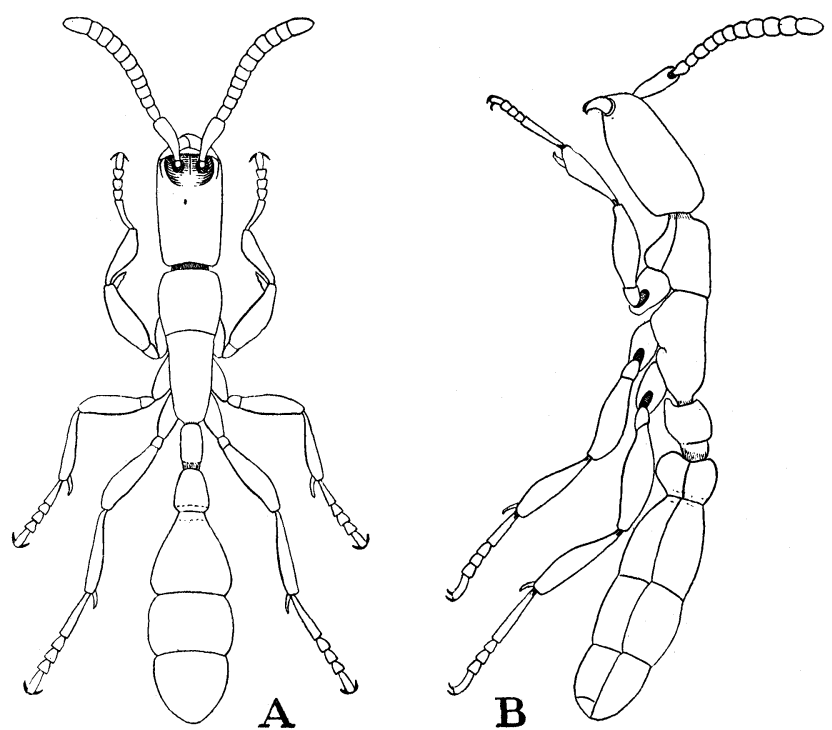

Fig. 1. Worker Leptanilloides biconstricta gen. nov. et sp. nov. A, dorsal, B, profile view.

Shining; head with abundant, separated, coarse, punctures; thorax and abdomen with much finer and sparser punctures. Head, body and appendges with abundant, rather coarse, short and erect, brownish hairs.

Color brownish red.

Type-Locality.-Tumupasa, Bolivia.

Cotypes.-Cat. No. 25905, U. S. N. M.

Described from a small series of workers, taken with callows, but without sexual or immature phases, from beneath a deeply embedded stone near a stream.

In general habitus this is very similar to Leptanilla, but the structure of the head associates it more closely with Eciton, from which it is distinct in the form of the frontal lamellæ, the form of the gaster and in not being polymorphic. 


\title{
Subfamily Ponerince.
}

Probolomyrmex? boliviensis sp. nov. (Fig. 2).

\author{
Female.-(deälated) Length $2.8 \mathrm{~mm}$.
}

Head about one and one-half times as long as broad, with slightly convex sides, rounded occipital angles and straight border; vertex and posterior portion of head broadly and evenly rounded, anterior part projected as a thick plate, broader than long and truncated in front, completely covering the mandibles. Clypeus on the anterior truncated portion, triangular, not sharply defined. Mandibles small and rather slender, blades rounding into the basal portions, with two indistinct and blunt teeth. Maxillary palpi 3-jointed, the first and second joints subequal in length and together as long as the third. Labial palp small, apparently 2-jointed. Frontal area rather large, feebly impressed. Frontal lamellæ fused into a high, thin plate, strongly convex in profile; behind separated and very short. Antennal insertions near front margin of head, bordered by a fine carina. Antennæ 12-jointed, scape extending about fourfifths the distance to occipital corners; funiculus evenly enlarged distally, without club; first funicular joint longer than broad; joints 2-10 transverse; terminal as long as the three preceding joints together. Eyes small, little convex, situated at middle of sides. Ocelli small. Thorax long and rather narrow, moderately convex above and at sides, humeri broadly rounded Mesonotum one and one-third times as long as broad. Scutellum longer than broad, rounded behind, with feeble impressions at middle of sides. Epinotum with feebly convex base and nearly flat declivity, bluntly dentate at angle. Petiole elongate nodiform; from above, twice as long as broad, with the posterior margin concave at middle and subdentiform at sides; in profile longer than broad and nearly twice as thick behind as in front, its ventral outline bisinuate, with a blunt antero-ventral tooth; posterior surface strongly concave. Gaster slender, strongly constricted between the first and second segments, first segment narrowed in front, shorter than the second, remaining segments small, directed downward. Sting well developed and strong. 
Legs long, rather slender, tibial spines coarse, those on posterior pair strongly pectinate.

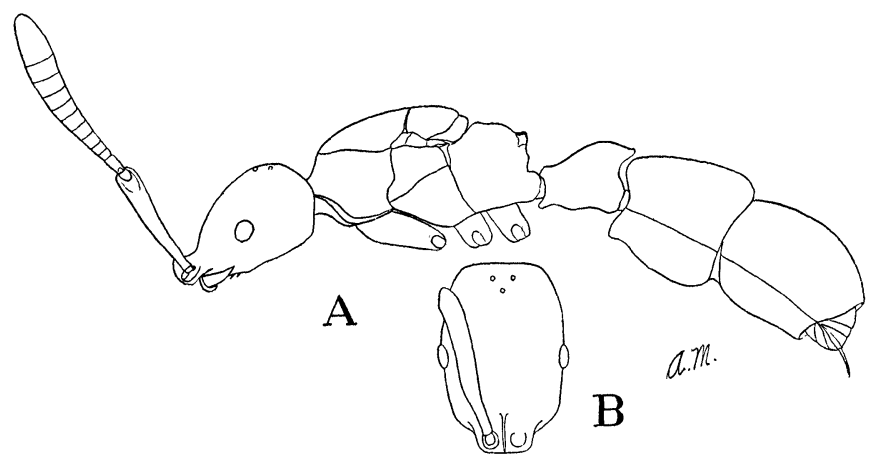

(Fig. 2. Female Probolomyrmex? boliviensıs sp. nov. A, profile view; B, head, dorsal view)

Opaque, finely, densely reticulate and in addition with rather coarse, foveolate punctures, especially prominent on the front of head, epinotum and gaster. Pubescence white, very fine, closely appressed, moderately abundant, more so on gaster and appendages.

Brownish red, appendages brownish yellow.

Type-locality.-Rurrenabaque, Bolivia.

Type.-Cat. No. 25906, U. S. N. M.

Described from a unique female found beneath a stone, near a small colony of Ponera sp.

In Probolomyrmex boliviensis the posterior segments of the gaster are much smaller, the antero-ventral petiolar spine is rounded and points forward and the epinotum is dentate rather than angulate, characters different from those in $P$. filiformis Mayr, but I can find no difference of generic value that would separate the two. In the worker of filiformis Mayr the posterior gastric segments are larger, the antero-ventral petiolar spine is lamellate and directed backward and the epinotum is angulate, instead of dentate. Perhaps when the female of filiformis or the 
worker of boliviensis is discovered it will be necessary to separate the two species generically, but the female of the latter resembles filiformis so closely, even to the curious Platythyrea-like sculpture, that had it been taken in South Africa, instead of South America, one would be tempted to regard it merely as the female of Mayr's species.

\section{A NEW GENUS OF MYRMECOPHILOUS PHORIDA, WITH NOTES ON SOME RELATED FORMS. ${ }^{2}$}

\section{By Charles T. Brues.}

Among the insects obtained by Dr. William M. Mann while a member of the Mulford Exploration in South America, are several species of wingless and subapterous Phoridæ. With the exception of a single species, all were taken in the nests of ants and are undoubtedly myrmecophilous. One, which proves to represent a new genus, occurs with Tranopelta, a hypogæic ant not hitherto known to harbor any phorid myrmecophiles, while the others are ecitophiles previously described from other parts of the South American continent.

The type of the new species is deposited in the United States National Museum.

Tranopeltoxenos gen. nov. (Fig. 1).

Entirely wingless. Head seen from above wide, twice as broad as long; antennæ widely separated, nearly round, their cavities separated; arista very short and thick, indistinctly pubescent; palpi strongly bristled; front with a series of six small, slightly proclinate, bristles along the anterior margin between the antennæ, and with eight macrochætæ disposed in two transverse rows; of these, the anterior row curves forward medially, with its lateral bristle behind the eye and the posterior row lies close to the occipital margin. Eyes very small; ocelli

1Results Mulford Biological Exploration.-Entomology.

2 Contribution from the Entomological Laboratory of the Bussey Institution, Harvard University. No. 215. 

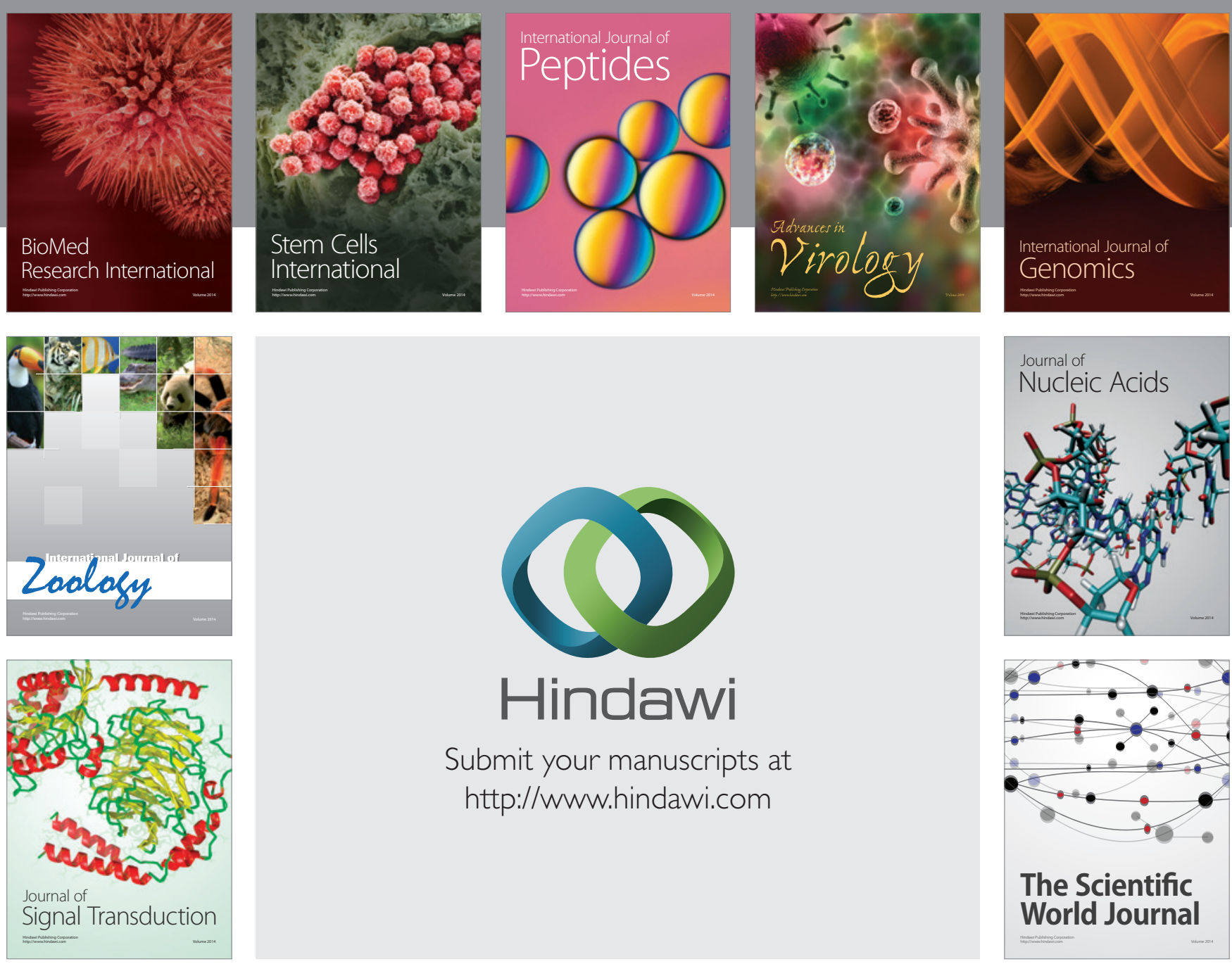

Submit your manuscripts at

http://www.hindawi.com
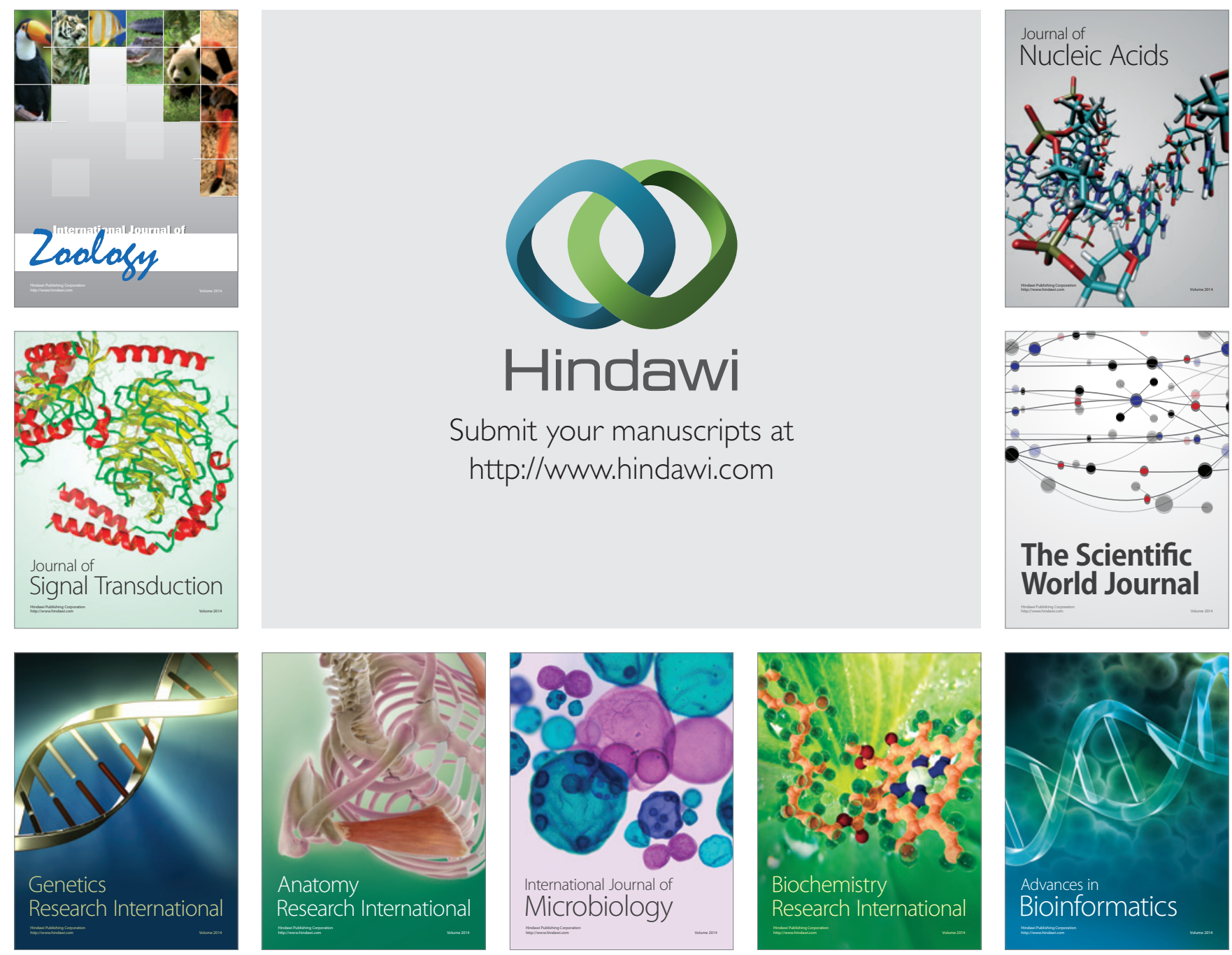

The Scientific World Journal
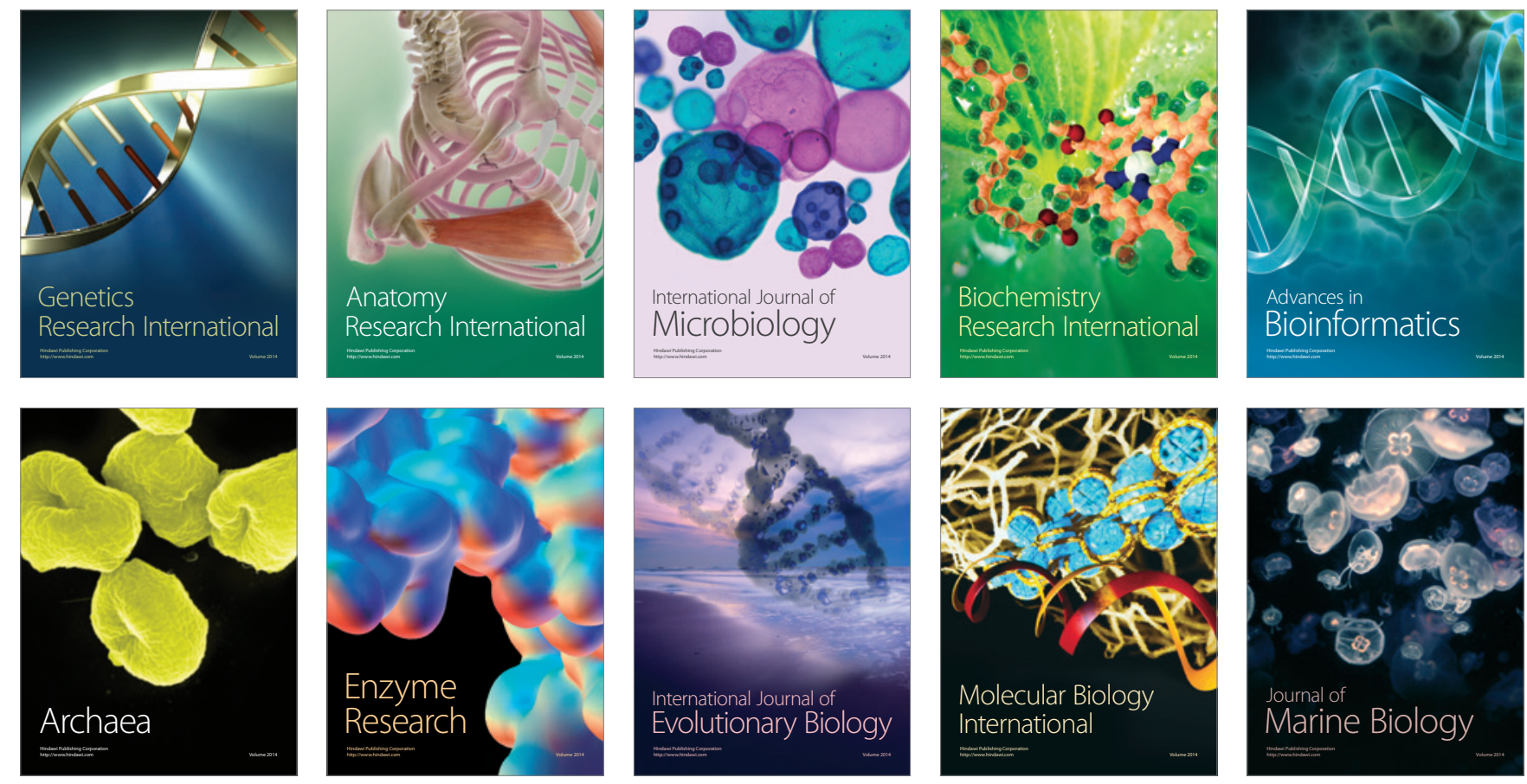